\title{
Nilai Idealisme dan Feminimisme dalam Novel Belenggu Merah Muda Karya Tyas Damaria
}

\author{
M. Taman \\ Universitas Indraprasta PGRI \\ Jalan Nangka No. 58 C/TB. Simatupang, Tanjung Barat, Jakarta Selatan 12530
}

\begin{abstract}
The purpose of this study was to determine the value of idealism and feminine values in the novel Belenggu Merah Muda by Tyas Damaria. The results of the analysis are that the values of subjective idealism are more dominant and the value of objective idealism is lower and the value of liberal feminism is more dominant and the value of anarchist feminism is lower in the novel Beleggu Merah Muda by Tyas Damaria. Seen from seventy eight (78) quotes with the following details: (1) the value of subjective idealism is 41\%, (2) the value of objective idealism is $17 \%$, (3) the value of personal idealism is 23\%. Besides that there are values of feminism as follows: (1) the value of feminism is $9 \%$, (2) the value of anarchist feminism is 7\%, (3) the value of radical feminism is $7 \%$.
\end{abstract}

Keywords: Value of Idealism, Value of Feminism.

\begin{abstract}
Abstrak
Tujuan dalam penelitian ini adalah untuk mengetahui nilai idealisme dan nilai feminimisem dalam novel Belenggu Merah Muda karya Tyas Damaria. Hasil dari analisis ialah nilai idealisme subjektif lebih dominan dan nyali idealisme objektif lebih rendah dan nilai feminisme liberal lebih dominan dan nilai feminisme anarkis lebih rendah dalam novel Belenggu Merah Muda Karya Tyas Damaria. Terlihat dari tujuh puluh delapan (78) kutipan dengan rincian sebagai berikut: (1) nilai idealisme subjektif sebanyak $41 \%$, (2) nilai idealisme objektif sebanyak $17 \%$, (3) nilai iidealisme personal sebanyak 23\%. Di samping itu terdapat nilai Feminisme sebagai berikut: (1) nilai feminimisme sebanyak $9 \%$, (2) nilai feminimisme anarkis sebanyak $7 \%$, (3) nilai feminimisme radikal sebanyak $7 \%$.
\end{abstract}

Kata Kunci: Nilai Idealisme, Nilai Feminimisme

\section{PENDAHULUAN}

Dewasa ini sebagian kaum perempuan masih aktif dalam perjuangan persamaan hak dengan kaum laki-laki atau yang lazim disebut kesetaraan gender. Di belahan dunia lain juga kita kenal Margareth Tacher, Madeleine Albright, dan Madonna perempuan genius dengan kepribadian yang kontraversial dan sangat sukses. Pada masa lalu kita mengenal Evita Peron dan masih banyak lagi. Selamat, kaum perempuan! Bahwa kaum perempuan mampu membuktikan bahwa potensi karir dan intelektual antara perempuan dan laki-laki adalah setara. Fenomena seperti ini, terjadi di Indonesia untuk kesetaraan gender. Keinginan dari kaum perempuan untuk diakui dan disetarakan dengan kaum laki-laki dalam pekerjaan maupun tugas tanpa menampilkan nilai-nilai idealis.

Novel Belenggu Merah Muda karya Tyas Damaria menjadi sebuah potret kehidupan tentang keinginan kaum wanita di Indonesia untuk disetarakan dengan 
kaum laki-laki. Oleh karena itu, analisis tentang idealisme dan feminisme untuk mengetahui kesesuaian yang ada dalam novel tersebut.

Idealisme merupakan tradisi pemikiran filsafat yang berpandangan bahwa doktrin tentang realitas eksternal tidak dapat dipahami secara terpisahkan dari kesadaran manusia. Kisah yang diangkat oleh Tyas Damaria dalam novelnya merupakan cerita tentang sebuah cerminan masyarakat saat ini yang rela memberikan semuanya hanya untuk cintanya. Perempuan sebagai ciptaan tuhan yang mempunyai pengikat dan daya tarik yang mampu memperalat lakilaki. Hal ini tentunya menjadi sebuah cerminan kehidupan saat ini.

Idealisme adalah doktrin yang mengajarkan bahwa hakikat dunia fisik hanya dapat dipahami dalam kebergantungannya pada jiwa (mind) dan roh (spirit). Istilah ini diambil dari kata "idea", yaitu sesuatu yang hadir dalam jiwa.Kata idealisme dalam filsafat mempunyai arti yang sangat berbeda dari arti yang biasa dipakai dalam bahasa sehari-hari. Kata idealis itu dapat mengandung beberapa pengertian, antara lain:Seorang yang menerima ukuran moral yang tinggi, estetika, dan agama serta menghayatinya;Orang yang dapat melukiskan dan menganjurkan suatu rencana atau program yang belum ada.

Arti falsafi dari kata idealisme ditentukan lebih banyak oleh arti dari kata ide daripada kata ideal. W.E. Hocking, seorang idealis mengatakan bahwa kata idea-ism lebih tepat digunakan daripada idealism. Secara ringkas idealisme mengatakan bahwa realitas terdiri dari ide-ide, pikiran-pikiran, akal (mind) atau jiwa (self) dan bukan benda material dan kekuatan. Idealisme menekankan mind sebagai hal yang lebih dahulu (primer) daripada materi. Juhaya (2003) mengemukakan bahwa ada beberapa jenis idealisme; yaitu idealisme subjektif, idealisme objektif, dan idealisme personal.

Fakih (dalam Sofia, 2009: 14) berpendapat bahwa feminisme berangkat dari asumsi bahwa perempuan pada dasarnya ditindas dan dieksploitasi. Puncak citacita feminis adalah menciptakan sebuah tatanan baru yang lebih baik dan lebih adil untuk laki-laki dan perempuan. Budianta (dalam Sofia, 2009: 13) mengartikan feminisme sebagai suatu kritik ideologis terhadap cara pandang yang mengabaikan permasalahan ketimpangan dan ketidakadilan dalam pemberian peran dan identitas sosial berdasarkan perbedaan jenis kelamin.

Perempuan dalam pandangan feminisme mempunyai aktivitas dan inisiatif sendiri untuk memperjuangkan hak dan kepentingan tersebut dalam gerakan untuk menuntut haknya sebagai manusia secara penuh (Kridalaksana dalam Sofia, 2009:13).

\section{Feminimisme Liberal}

Fakih (dalam Sofia, 2009:14) Feminisme liberal adalah feminisme yang memandang adanya kolerasi positif antara partisipasi dalam produksi dan status perempuan. Kaum feminis liberal berkeinginan agar manusia, laki-laki dan perempuan mengembangkan kepribadiannya yang tidak mengaitkan derajat hierarki dengan jenis kelaminnya (androgini) (Tong dalam Wiyatmi, 2012:19).

Feminisme liberal memandang wanita perlu diperjuangkan sepenuhnya sama dengan laki-laki baik itu hak suara, pendidikan maupun kesamaan dalam hukum. Jadi wanita memiliki kebebasan individual dan secara penuh.

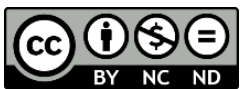


Feminisme liberal ini melahirkan hukum, tatanan dan aturan termasuk norma yang dikonvensi secara lisan dalam tradisional yang bertanggung jawab atas penindasan dan subordinasi wanita. Masyarakat menganggap wanita secara ilmiah kurang memiliki kemampuan intelektualitas dan fisik maka dianggap tidak layak untuk diberi peran di lingkungan publik.

\section{Feminisme Anarkis}

Feminisme Anarkis lebih bersifat sebagai suatu paham politik yang mencita-citakan masyarakat sosialis dan menganggap negara dan sistem patriarkidominasi lelaki adalah sumber permasalahan yang sesegera mungkin harus dihancurkan.

\section{Feminisme Radikal}

Feminisme radikal beranggapan bahwa penguasaan fisik perempuan oleh laki-laki, seperti hubungan seksual adalah bentuk penindasan terhadap kaum perempuan, bagi penganut feminism radikal, patriarki adalah dasar dari ideologi penindasan yang merupakan sistem hierarki seksual yang dalam hal ini laki-laki memiliki kekuasaan superior dan privilage ekonomi (Sofia, 2009:13).

Dalam penelitian ini, peneliti akan memaparkan temuan-temuan data berdasarkan pesan secara umum, mewacanakannya dan mendeskripsikan kalimatkalimat yang memiliki muatan-muatan sebagai aspek tersebut. Terkait dengan hal tersebut maka, mengetahui aspek kepribadian tersebut, terlebih dahulu peneliti akan mendeskripsikan pesan-pesan secara umum berdasarkan analisis teks.

Pengarang menyampaikan idealisme melalui novelnya antara lain semangat nasionalisme yang memiliki tokoh-tokoh dalam cerita yang diharapkan dapat membuka pikiran pembaca untuk selalu berjuang untuk selalu berjuang untuk mewujudkan kesejahteraan hidupnya dan bangsanya

\section{METODE}

Metode dalam penelitian ini menggunakan metode kualitatif. Metode ini mengacu pada deskripsi data korpus atau kalimat dari novel Belenggu Merah Muda karya Tyas Damaria. Data korpus atau kalimat yang diambil adalah deskripsi paparan pengarang novel Belenggu Merah Muda karya Tyas Damaria. Nilai yang akan dikaji adalah nilai idealisme dan feminisme dalam novel tersebut. Sugiyono (2012: 36) berpendapat tentang penggunaan metode kualitatif dalam penelitian, yaitu: Untuk mengembangkan teori. Metode kualitatif paling cocok digunakan untuk mengembangkan teori yang dibangun melalui data yang diperoleh melalui lapangan. Teori yang demikian dibangun melalui grounded research. Dengan metode kualitatif peneliti pada awalnya melakukan penjelajahan, selanjutnya melakukan pengumpulan data yang mendalam sehingga ditemukan hipotesis yang berupa hubungan antargejala. Hipotesis tersebut diverifikasi dengan pengumpulan data yang mendalam. Bila hipotesis terbukti, maka akn menjadi tesis atau teori.

Fokus dalam penelitian ini yang dibahas adalah nilai idealisme dan nilai feminimisme yang terdapat dalam novel Belenggu Merah Muda karya Tyas 
Damaria. Subfokus Fokus peneltian ini dikembangkan menjadi dua subfokus penelitian, yaitu: (1) Struktur (tokoh, alur, latar, dan tema,) dalam novel Belenggu Merah Muda karya Tyas Damaria.

Instrumen penelitian ini adalah peneliti sendiri (human instrument) yang dibantu dengan tabel analisis, bertujuan untuk mengumpulkan dan mengolah datadata sehingga dapat mempermudah peneliti dalam menganalisis serta mendeskripsikan analisis aspek idealisme dan aspek Feminisme dalam novel Gajah Mada Karya Langit Kresna Hariadi. Penelitian dilakukan dengan menggunakan instrumen berbentuk tabel analisis. Tabel tersebut ialah tabel mengenai kelainan identitas gender yang dideskripsikan ke dalam unsur Feminimisme Sigmund Freud.

Prosedur yang ditempuh dalam pengumpulan data yaitu membaca novel Belenggu Merah Muda karya Tyas Damaria, mencatat seluruh korpus yang berhubungan dengan deskripsi nilai idealisme dan feminisme, memahami isi kalimat sebagai langkah mengelompokkan nilai idealisme dan feminisme yang terdapat di dalamnya, memberikan interpretasi terhadap temuan dan kalimat yang berupa deskripsi nilai idealisme dan feminisme, mempresentasikan temuan dan menyimpulkan hasil penelitian, mengategorisasi tabel berdasarkan fokus penelitian, menjelaskan secara deskriptif hasil kategori tabel analisis, dan menyimpulkan hasil penelitian.

\section{HASIL DAN PEMBAHASAN}

Dalam penelitian ini, peneliti akan memaparkan temuan-temuan data berdasarkan pesan secara umum, mewacanakannya dan mendeskripsikan kalimatkalimat yang memiliki muatan-muatan sebagai aspek tersebut. Terkait dengan hal tersebut maka, mengetahui aspek kepribadian tersebut, terlebih dahulu peneliti akan mendeskripsikan pesan-pesan secara umum berdasarkan analisis teks.

Pengarang menyampaikan idealisme melalui novelnya antara lain semangat nasionalisme yang memiliki tokoh-tokoh dalam cerita yang diharapkan dapat membuka pikiran pembaca untuk selalu berjuang untuk selalu berjuang untuk mewujudkan kesejahteraan hidupnya dan bangsanya. Berikut temuan yang didapatkan:

"Laras, Aku di sini bukan bermaksud jahat. Aku ingin menolongmu. Arga bilang bahwa penajara sebenarnya bukan tempatmu. Karena itu dia mengirimku untuk mendampingimu."

Dari uraian di atas dapat disimpulkan bahwa seorang perempuan tidak pantas untuk dihukum di dalam penjara. Seorang perempuan yang memiliki sikap lemah lembut dan kasih sayang tidak sepantasnya hidup dalam dunia kelam.

"Istighfar, Laras.... Jangan berburuk sangka kepada-Nya. Tuhan akan selalu menuntun kita untuk berusaha. Laras, Dia hanya menguji sebesar apa usaha kita, dan seberapa dekat kita dengan-Nya, dari sanalah akan muncul titik terang. 
Dari uraian di atas dapat disimpulkan bahwa seorang manusia yang diciptakan oleh Tuhan Yang Maha Esa, hendaklah mempunyai keyakinan tentang hikmah kebaikan dari segala ujian yang diberikan-Nya.

Dari dua uraian di atas dapat disimpulkan bahwa idealisme subjektif yang bersumber dari ide. Idealisme subjektif yang bersumber dari ide lain adalah tentang pergaulan para sosialita dan kisah cintanya yang berlabuh kepada seorang pejabat dengan karier yang tengah menanjak. Cinta yang dirasakan, membuatnya buta sehingga merelakan segalanya. Hukuman penjara atas pengorbanannya membuatnya sadar, dan kemudian mulai menata dirinya kearah lebih baik.

Semerbak aroma asam keringat bercampur besi tercium diantara kami. Aku sadar aroma itu bersumber dari tubuhku. Sudah pasti perempuan di depanku ini merasa risi dan terganggu dengan bau tak sedap ini, tapi aku sudah tak punya urat malu. Untuk apa masih menyimpan rasa malu di saat hidupku sudah hancur lebur dan menghabiskan waktu di balik jeruji.

Peristiwa di atas menggambarkan tentang keadaan di dalam rumah tahanan perempuan yang ada di Indonesia yang sudah penuh sesak dengan para tahanan dengan berbagai kejahatan.

Mobil Arga melaju cepat menerobos gerbang perumahannya tanpa bertegur sapa dengan security seperti kebiasannya. Dia memarkir mobilnya di carport rumahnya dengan tergesa, kemudian turun dari mobil dengan wajah kesal.

Peristiwa di atas menggambarkan tentang keadaan seseorang yang dirundung masalah, pikirannya bercampur aduk tanpa mau melihat dan memperhatikan keadaan sekitarnya.

Dari dua uraian diatas dapat disimpulkan bahwa idealisme Objektif adalah idealisme yang bertitik tolak pada ide di luar ide manusia. Idealisme objektif ini dikatakan bahwa akal menemukan apa yang sudah terdapat dalam susunan alam

"Nah, Lara, kamu sekarang mengerti kan, kamu memiliki takdir menjadi pengusaha? Bahkan kecantikan yang kamu miliki akan membuatmu menjadi sosialita populer. Sosialita dan dunia bisnis itu dekat. Kurang apa lagi, Laras?" Dari uraian di atas dapat disimpulkan bahwa pengorbanan dan usaha dilakukan untuk melindungi dan menyelamatkan Raja Majapahit. Hal itu merupakan bentuk kesetian dan kecintaan para abdi dalem dan rakyat terhadap raja yang mereka hormati."

Dari uraian di atas dapat disimpulkan bahwa manusia yang diberikan kelebihan oleh Tuhan berupa paras yang cantik dan ganteng, terkadang oleh manusia tersebut dijadikan alat untu apa pun.

Aku terdiam. Andin menangkap keterkejutanku akan perubahan dirinya. "Realita dan keinginan tidak selalu sama, Laras. Mungkin dulu kita 
sama-sama naif, berharap hidup akan bahagia jika mendapatkan laki-laki mapan. Tapi kenyataannya berbanding terbalik dengan harapan. Jadi yang menderita bukan kamu sendiri. I've been there," lanjutnya seraya tersenyum simpul

Dari uraian di atas dapat disimpulkan bahwa hingar binger ibukota membuat sebaian orang terpana dan terpesona olehnya. Cara cepat untuk kehidupan yang lebih menyenangkan dan bergelimang harta adalah menikahi pasangan yang mapan. Namun harapan tidak sesuai dengan kenyataan yang ada. Uraian ini merupakan bentuk idealisme personal.

“Good evening, Arga....” balas beberapa perempuan dengan kompak. Seakan-akan kaliamt sapaan itu menjadi kata ditujukkan khusus untuk mereka personal. Aku tersenyum geli, karena reaksi antusias mereka mengingatkanku pada ketiga Charlie's Angels saat disapa Charlie. Tapi di sisi lain, aku mengakui karisma laki-laki itu memang kuat. Entah bagaimana dia mampu mengisap perhatian perempuan, karena hal itu pun aku rasakan.

Kutipan di atas dapat disimpulkan bahwa seorang perempuan yang ingin selalu disayangi dan diperhatikan, ketika melihat lelaki yang mereka impikan dan anggap sempurna, mereka berusaha mencoba menarik perhatian lawan jenisnya. Temuan tersebut merupakan bentuk dari feminimisme liberal.

Tibalah giliranku menyalami Arga. Andiin mengenalkanku dengan penekanan pada status 'pengusaha mebel yang hebat'. Lelaki itu melayangkan kekaguman saat menggenggam tanganku. Kuakui, dalam jarak dekat, aura Arga mampu menggetarkanku. Mungkin inilah yang dirasakan para perempuan yang berdekatan dengannnya.

Kutipan di atas dapat disimpulkan bahwa keinginan kesetaraan gender untuk sebuah pengakuan sering ditonjolkan oleh kaum perempuan, ia berusaha menonjolkan kemampuan dan kelebihan yang ia miliki terhadap kaum laki-laki.

"Betul-betul perempuan yang tidak punya hati. Alih-alih mengaku sebagai seorang istri yang trzolimi atas perselingkuhan suaminya, tapi justru sebenarnya perempuan seperti inilah yang menjadi alasan utama laki-laki untuk berselingkuh. Dan tipe perempuan seperti inilah yang bisa mengantarkan suaminya untuk menghalalkan segala cara yang berujung pada perbuatan melanggar hukum demi memenuhi kebutuhan istrinya"

Kutipan di atas dapat disimpulkan bahwa semua perempuan menginginkan kehidpuan yang bahagia, dicintai dan disayangi oleh seorang laki-laki. Bisa membahagiakan anak dan dan keluarganya. Temuan ini merupakan bentuk dari feminimisme anarkis.

"Tapi, begitu suami meninggal, segala beban berpindah ke bahu isterinya," ujarku berusaha terdengar santai. Seketika mereka menunjukkan 
ekspresi simpati saat mengetahui aku ditinggal mati suami. Namun keprihatinan itu hanya sesaat kemudian mereka terfokus pada bisnisku."

Kutipan di atas dapat disimpulkan bahwa kewajiban orang tua terhadap anaknya sampai ia sudah dapat bisa mandiri. Tanggung jawab tersebut untuk urusan dunia dan akhirat. Temuan tersebut merupakan bagaian dari bentuk feminimmisme anarkis.

"Arletta, kamu harus tahu betapa gamangnya aku saat itu? Hati kecilku berkata untuk tidak meneruskan hubunganku dengan Arga, tapi di sisi lain kami saling membutuhkan. Dia mampu meredakan kesepianku."

Kutipan di atas dapat disimpulkan bahwa perempuan selalu menyadari adanya ketidakadilan dalam gender. Laki-laki sama perempuan memang jauh berbeda. Hakikat seorang lebih terbatas ruang geraknya dibanding perempuan. Temuan tersebut merupakn bagian dari bentuk feminimisme radikal.

"Simpan saja air matamu, Arga. Pikirkan saja kenapa kamu punya hati sepicik ini. Pikirkan baik-baik, sebelum perempuan-perempuan lan menjadi korban keluargamu ." ucapku datar. Lalu aku beridiri, meninggalkan Arga bergetar dan mengenggam surat dariku."

Kutipan di atas dapat disimpulkan bahwa perempuan selalu menyadari adanya ketidakadilan dalam gender. Laki-laki sama perempuan memang jauh berbeda. Hakikat seorang lebih terbatas ruang geraknya dibanding perempuan. Temuan ini merupakan bentuk dari feminimisme radikal.

Berdasarkan hasil penelitian yang telah dilakukan pada nilai idealisme dan nilai feminisme novel Beleggu Merah Muda Karya Tyas Damaria maka dapat diketahui. (1) Nilai idealisme subjektif lebih dominan dan nilai idealisme objektif lebih rendah dalam novel Beleggu Merah Muda Karya Tyas Damaria, (2) Nilai feminisme liberal lebih dominan dan nilai feminisme anarkis lebih rendah.

Novel Belenggu Merah Muda karya Tyas Damaria memiliki. Novel Belenggu Merah Muda Karya Tyas Damaria menjadi sebuah potret kehidupan tentang keinginan kaum wanita di Indonesia untuk disayangi dan dicintai oleh kaum laki-laki dengan sebenarnya. Sesungguhnya hakikat seorang perempuan memiliki hati yang lembut. Oleh karena itu, dilakukan analisis tentang idealisme dan feminisme untuk mengetahui kesesuaian yang ada dalam novel tersebut. Semua hal ini tentunya merupakan nilai-nilai yang terkandung dalam novel yang layak dijadikan sebuah pesan yang sangat bermakna bagi pembacanya. Selain dari sisi cerita yang disajikan, penulis novel ini pun memiliki kepiawaian tersendiri dalam menuliskan cerita dalam novel ini, terbukti dengan cerita yang sangat kompleks dan selalu ada kejutan dalam setiap bagian-bagian dalam novel ini.

Novel Belenggu Merah Muda karya Tyas Damaria mempunyai beberapa sisi kelebihan dari novel yang lainnya, yaitu merupakan novel yang memiliki aspek idealisme. Novel ini adalah novel yang segmen pembacanya masuk ke dalam semua kalangan dan di dalamnya mengandung hakikat dalam kehidupan. Aspek yang lain 
pun banyak diuraikan dalam bagian alur cerita yang membangun, seperti pada unsur idealisme subjektif, idealisme objektif, dan idealisme personal yang banyak membahas kehidupan masyarakat dengan segala macam problematika dengan lingkungannya. Selain hal tersebut juga tergambar uraian feminisms seperti, liberal, anarkis, dan radikal.

\section{SIMPULAN}

Berdasarkan uraian di atas, dapat disimpulkan bahwa pada novel Belenggu Merah Muda Karya Tyas Damaria, yaitu: Nilai idealisme subjektif lebih dominan daripada nilai idealisme lainnya dan nilai feminisme liberal lebih dominan daripada nilai feminisme lainnya.

\section{DAFTAR PUSTAKA}

Aminuddin. (2002). Pengantar apresiasi sastra. Bandung: Sinar Baru Algesindo. Arifin, E. Z. (2008). Dasar-dasar penulisan karya ilmiah. Jakarta: Grasindo.

Ihsan, A. F. (2010). Filsafat ilmu. Jakarta: Rineka Cipta.

Juhaya S Praja. 2003. Aliran-aliran Filsafat \& Etika. Jakarta: Fajar IInter Pratama. Kosasih, E. (2012). Dasar-dasar keterampilan bersastra. Bandung: Yrama Widya. Nurgiyantoro, B. (2009). Teori pengkajian fiksi. Yogyakarta: Gadjah Mada University Press.

Pradopo, R. D. (2007). Prinsip-prinsip kritik sastra. Yogyakarta: Gajah Mada University Press.

Ratna, N. K. (2012). Penelitian sastra. Yogyakarta: Pustaka Pelajar.

Sofia., \& Sugihastuti. (2003). Feminimisme dan Sastra. Bandung: Kataris

Sofia, A. (2009). Aplikasi Kritik Sastra Feminimisme Perempuan dalam Karyakarya Kuntowijoyo. Yogyayakarta: Pustaka Pelajar

Sudarsono. (2008). Ilmu filsafat. Jakarta: Rineka Cipta.

Sugiyono. (2012). Metode penelitian pendidikan. Bandung: Alfabeta.

Sumaryoto. (2015). Panduan penulisan skripsi, tugas akhir, dan tesis. Jakarta: Unindra Press.

Waluyo, H. J. (2002). Apresiasi Puisi. Jakarta: Gramedia Pustaka Utama.

Minderop, A. (2010). Psikologi Sastra. Jakarta: Gramedia Pustaka Utama.

Sudjiman, P. (1991). Memahami Cerita Rekaan. Jakarta: Pustaka Jaya.

Moleong, L. J. (2007). Metodologi Penelitian Kualitatif. Bandung: Remaja Rosdakarya.

Wellek, R., \& Warren, A. (1995). Teori Kesusastraan. Jakarta: PT Gramedia Pustaka Utama 